\title{
Pengembangan Bahan Ajar Matematika Menggunakan KOMPUTER PADA MATERI KESEBANGUNAN DI KELAS IX MTS Negeri 1 Palembang
}

\author{
THE DEVELOPMENT OF MATHEMATICAL TEACHING MATERIALS USING \\ Computer on Congruency Topic in Class IX MTS State 1 Palembang
}

\author{
Veven Hernandes ${ }^{1}$, Muhammad Isnaini ${ }^{2}$ and Gusmelia Testiana ${ }^{3}$ \\ 1,2,3 Universitas Islam Negeri Raden Fatah Palembang \\ Palembang, Sumatera Selatan, Indonesia \\ veven_h@yahoo.com
}

\begin{abstract}
Abstrak
Penelitian ini bertujuan menghasilkan bahan ajar matematika dengan menggunakan komputer pada materi kesebangunan untuk sekolah menengah pertama yang memenuhi kriteria valid dan praktis untuk digunakan dalam kegiatan pembelajaran matematika serta agar siswa lebih tertarik belajar pelajaran matematika.Metode yang digunakan dalam penelitian ini adalah metode Research and Development (R \& D). Subyek dalam penelitian ini ada dua kelas yaitu siswa kelas IXCyang berjumlah 40 siswa sebagai kelompok besar dan 10 siswa dari 40 siswa kelas IXA sebagai kelompok kecil. Teknik pengumpulan data yang digunakan pada penelitian ini adalah lembar validasi, angket kepraktisan dan observasi kepraktisan. Berdasarkan hasil validasidari 6 validator diperoleh skor rata-rata sebesar 88,73 yang tergolong kategori sangat valid. Berdasarkan angket kepraktisan pada tahap uji coba produk kelompok kecildiperoleh hasil rata-rata dalam kategori praktisyaitu 89,38 dan rata-rata observasidalam kategori praktis yaitu sebesar 85 . Sedangkan pada tahap uji pemakaian kelompok besar diperoleh hasil rata-rata dalam kategori praktis yaitu 85,26 dan rata-rata observasi dalam kategori praktis yaitu sebesar 85,24 . Sehingga bahan ajar matematikayang dikembangkan dapat digunakan dalam pembelajaran kesebangunan.
\end{abstract}

Kata Kunci: Bahan ajar matematika, kesebangunan, valid, praktis.

\begin{abstract}
This study aims to produce a mathematics instructional materials using a computer on the material similarity for junior high school which meet the criteria for a valid and practical use in mathematics learning activities as well as to make students more interested in learning math. The method used in this research is the Research and Development $(R \& D)$. Subjects in this studyare two classes, 40 students from IXC as a large group and 10 of 40 students from IXA as a small group. Data collection techniques used in this study are validation sheet, questionnaire and practicality observation. Based on the results of the validation of the 6 validators obtained an average score of 88.73 which is classified as a very valid one. Based on the practicality questionnaire of the small group's test phase obtained a result of $89.38 \%$ with the average $92.5 \%$ in practical category. Meanwhile in the larger group's test phase obtained a result of $85.26 \%$ with the average $94.32 \%$ in practical category. So that the mathematical teaching materials developed can be used in learning similarity.
\end{abstract}

Keyword: mathematical teaching materials, similarity, valid, practical. 


\section{Pendahuluan}

Dalam Undang-undang Tentang Sistem Pendidikan Nasional No. 20 Tahun 2003, Bab 1 Pasal 1 Ayat 1 mengemukakan Pendidikan adalah usaha sadar dan terencana untuk mewujudkan suasana belajar dan proses pembelajaran agar peserta didik secara aktif mengembangkan potensi dirinya untuk memilih kekuatan spiritual keagamaan, pengendalian diri, kepribadian, kecerdasan, ahlak mulia, serta keterampilan yang diperlukan dirinya, masyarakat bangsa dan negara. Maka untuk melaksanakan tujuan pendidikan agar tujuan pendidikan tersebut tercapai diperlukan tenaga pendidikan yang berkualitas dalam mendidik peserta didik. Tenaga pendidik atau guru memiliki peran penting dalam proses pembelajaran oleh karena itu guru dituntut untuk melakukan segala cara agar tujuan pendidikan dapat dicapai dengan baik.

Ada banyak cara yang dapat dilakukan guru agar peserta didik dapat mengerti dan memahami apa yang disampaikan oleh guru, diantaranya memanfaatkan metodemetode pembelajaran, pendekatan pembelajaran, media pembelajaran dan lain-lain. Pada zaman sekarang ini perkembangan ilmu dan teknologi semakin mendorong usaha-usaha kearah pembaharuan dalam memanfaatkan hasilhasil teknologi dalam pelaksanaan pembelajaran. Melalui media pembelajaran, guru dapat menyajikan bahan pelajaran yang bersifat abstrak menjadi konkret, sehingga mudah dipelajari dan dapat menghilangkan verbalisme. Selain itu media pembelajaran juga bisa membantu menampilkan objek yang terlalu besar, yang tidak mungkin dapat ditampilkan didalam kelas, atau menampilkan objek yang terlalu kecil [1].

Ada banyak macam media yang dapat dimanfaatkan oleh guru. Salah satunya adalah media berbasis komputer. Komputer adalah mesin yang dirancang khusus untuk memanipulasi informasi yang diberi kode, serta merupakan mesin elektronik yang otomatis melakukan pekerjaan dan perhitungan sederhana dan rumit [2]. Komputer dapat berperan sebagai pembantu tambahan belajar dan pemanfaatanya meliputi penyajian informasi isi materi pelajaran, latihan, atau kedua-duanya. Komputer merupakan salah satu teknologi informasi yang memiliki potensi besar untuk meningkatkan kualitas pembelajaran, khususnya dalam pembelajaran matematika.

Berdasarkan hasil observasi awal yang dilakukan peneliti di MTs Negeri 1 Palembang pada tanggal 15 November 2014 bahwa siswa menganggap pelajaran matematika adalah pelajaran yang sulit untuk di pelajari sehingga siswa takut dan kurang tertarik untuk belajar matematika. bahan ajar yang digunakan di MTs Negeri 1 Palembang sudah menggunakan LKS (Lembar Kerja Siswa) untuk semua mata pelajaran, tidak terkecuali pelajaran matematika. Bahan ajar LKS biasanya terdapat gambar-gambar yang mendukung agar siswa lebih tertarik untuk belajar matematika, akan tetapi jika gambargambar tersebut bisa bergerak sehingga dapat menjelaskan materi yang sedang dipelajari maka siswa akan lebih tertarik untuk belajar matematika 
Dari beberapa uraian diatas maka peneliti tertarik untuk Mengembangkan bahan ajar matematikamenggunakan komputerpada materi kesebangunan di kelas IX MTs Negeri 1 Palembang.

\section{Metode}

Jenis penelitian ini adalah penelitian dan pengembangan atau Research and Development. Metode penelitian dan pengembangan atau research and development adalah metode penelitian yang digunakan untuk menghasilkan produk tertentu. Subyek penelitian ini adalah kelas IX Madrasah Tsanawiyah (MTs) Negeri 1 Palembang pada semester ganjil tahun ajaran 2015/2016. Kelas yang menjadi subyek penelitian ini adalah kelas IX A dan IX $C$ dipilih secara acak sederhana.

Langkah-langkah penelitian dan pengembangan yaitu sebagai berikut [3]:

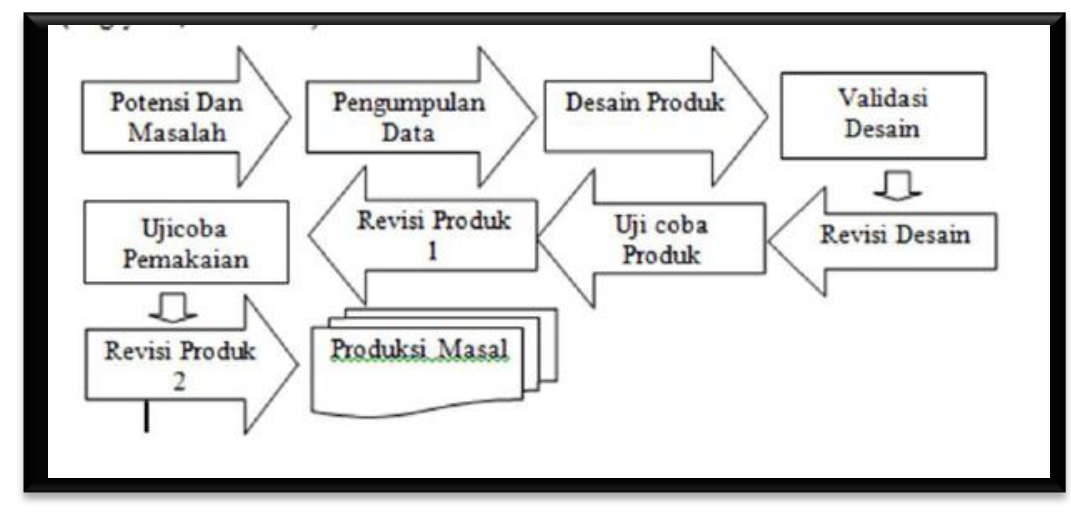

Gambar 1. Langkah-langkah metode Research and Development (R \& D)

1. Potensi dan Masalah

Tahap pertama pengembangan ini adalah menentukan materi bahan ajar yang dikembangkan dengan menggunakan Adobe Flash CS6 pofesional. Materi yang dikembangkan yaitu kesebangunan.

2. Mengumpulkan Data

Pada tahap ini peneliti menghubungi guru di sekolah guna mengumpulkan data yang diperlukan, mengobservasi kondisi laboratorium tempat penelitian, dan mempersiapkan prosedur kerjasama untuk mendukung terlaksananya penelitian.

\section{Desain Produk}

Pada tahap ini peneliti mendesain atau merancang bahan ajar matematika pada materi kesebangunan dengan menggunakanAdobe Flash CS6 Profesional. Pada tahap ini hasildesain produk dinamakan prototype pertama.

4. Validasi Desain

Pada tahap ini dilakukan validasi prototipe pertama. Validasi ini dilakukan untuk mengetahui KevalidanBahan Ajar Matematika yang dirancang untuk Siswa Kelas IX di MTs Negeri 1 Palembangdengan Adobe Flash CS6 Profesional. Validasi dilakukan oleh para ahli yaitu dosen dan guru. Adapun kategori validasi yang dinilai yakni katogori Content (isi), Construct (konstruk dan navigasi), dan Bahasa. 
5. Perbaikan desain

Setelah prototype pertama divalidasi melalui penilaian para ahli maka akan dapat diketahui kelemahannya. Selanjutnya peneliti melakukan revisi berdasarkan masukan dari para ahli untuk mengatasi kelemahan tersebut. Setelah melalui tahap ini, bahan ajar dapat dikatakan valid dan menghasilkan prototype kedua.

\section{Uji Coba Produk}

Setelah perbaikan desain, langkah selanjutnya prototipe kedua dapat langsung diuji coba setelah divalidasi dan revisi. Uji coba tahap ini dilakukan dengan kelompok kecil yang terdiri dari 10 siswa kelas IXyang merupakan bagian dari subyek penelitian. Uji coba dilakukan untuk melihat kepraktisan prototype kedua serta untuk melihat hasil belajar 10 siswa tersebut dengan menggunakan prototype kedua.

7. Revisi produk

Pada tahap ini peneliti melakukan revisi prototype kedua berdasarkan hasil dari uji coba prototype kedua pada 10 siswa kelas IX. setelah melaui tahap ini bahan ajar yang telah direvisi dinamakanprototype ketiga.

8. Uji coba pemakaian
Setelah revisi, pada tahap ini dilakukan uji coba pada siswa yang menjadi subyek penelitian. Uji coba dilakukan untuk melihat kepraktisan prototipe ketigadan hasil belajar siswa kelas IX yang menjadi subyek penelitian dengan menggunakan prototype ketiga.

9. Revisi produk tahap akhir

Pada tahap ini, peneliti melakukan revisi tahap akhir jika masih terdapat kekurangan berdasarkan hasil dari tahapuji coba pemakaian. Pada tahap ini setelah melakukan revisi pada prototype ketiga

10. Produksi massal

Pada tahap ini Bahan Ajar Matematika yang dikembangkan dapat digunakan untuk kelas IX SMP//MTs pada materi pembelajaran kesebangunan.

\section{A. Analisis Lembar Validasi}

Produk yang telah divalidasi kemudian dinilai oleh dosen pendidikan matematika dan guru dengan memberikan tanda ceklist $(\sqrt{ })$ pada kolom yang telah disediakan pada lembar validasi. Adapun arti nilai atau angka-angka pada skala penilaian yang berada pada lembar validasi adalah [3]:

$1=$ Tidak baik $\quad 2=$ Kurang baik

$3=$ Cukup Baik $\quad 4=$ Baik

$5=$ Sangat baik

Tabel 1.

Lembar Validasi [4]

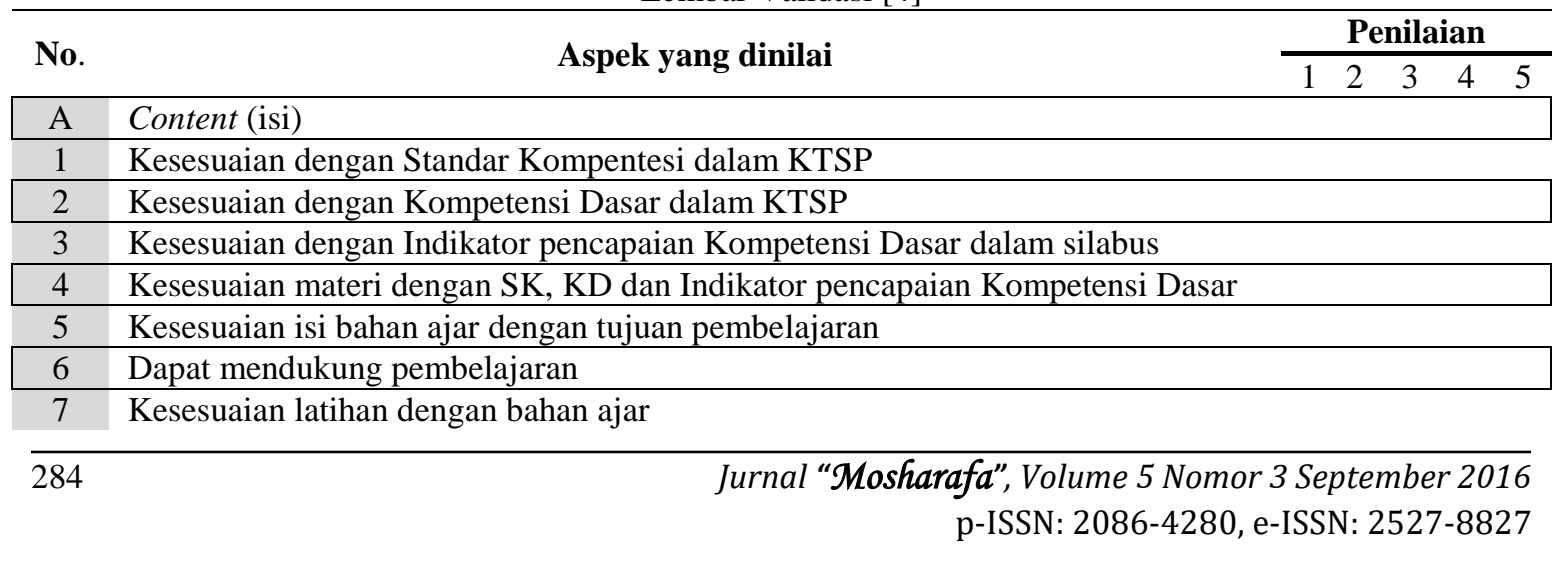




\begin{tabular}{|cl|}
\hline 8 & Kebenaran isi Materi \\
\hline 9 & Kecukupan Materi \\
\hline 10 & Kedalaman materi \\
\hline B & Construct (struktur dan navigasi) \\
\hline 1 & Pengelompokan materi \\
\hline 2 & Urutan materi \\
\hline 3 & Konsistensi letak menu \\
\hline 4 & Susunan materi dapat mengkonstruk pengetahuan siswa \\
\hline 5 & Fungsi tombol \\
\hline 6 & Komposisi warna \\
\hline 7 & Pemakaian suara \\
\hline & \\
\hline C & Bahasa \\
\hline 1 & Rumusan masalah komunikatif \\
\hline 2 & $\begin{array}{l}\text { Kalimat menggunakan bahasa baik dan benar, serta sesuai dengan ragam } \\
\text { bahasanya }\end{array}$ \\
\hline 3 & Rumusan kalimat tidak menimbulkan penafsiran ganda, atau salah pengertian \\
\hline 4 & Konsistensi huruf dan gambar \\
\hline
\end{tabular}

Berdasarkan lembar validasi yang telah diisi oleh dosen ahli. dimana skor setiap dosen diperoleh dari jumlah skor 21 butir pertanyaan sebagaimana yang tercantum dalam format validasi. Data hasil validasi dikonversikan menjadi interval 0-100:

$$
H=\frac{J S}{S T} X 100
$$

Keterangan:

$\mathrm{H}$ : Hasil Validasi

JS : Jumlah Skor

ST : Skor Maksimum

Tabel 2.

Kategori skor validasi [5]

\begin{tabular}{|cc|}
\hline Skor & $\begin{array}{l}\text { Kualitas Produk Bahan Ajar } \\
\text { Matematika }\end{array}$ \\
\hline $81-100$ & Sangat Valid \\
\hline $61-80$ & Valid \\
\hline $41-60$ & Cukup Valid \\
\hline $21-40$ & Kurang Valid \\
\hline $0-20$ & Tidak Valid \\
\hline
\end{tabular}

\section{B. Analisis Angket Respon Siswa}

Langkah-langkah untuk menganalisis data angket pada penelitian ini adalah :
1. Memberikan skor terhadap setiap jawaban siswa. Setiap alternatif pilihan jawaban diberi skor 1-4. Skor setiap alternatif pilihan jawaban ditetapkan pada tabel sebagai berikut:

Tabel 3.

Alternatif pilihan jawaban angket bahan ajar matematika [6]

\begin{tabular}{|cc|}
\hline Skor & $\begin{array}{c}\text { Alternatif pilihan } \\
\text { jawaban }\end{array}$ \\
\hline 4 & Sangat Setuju (SS) \\
\hline 3 & Setuju (S) \\
\hline 2 & Tidak Setuju (TS) \\
\hline 1 & Sangat Tidak Setuju (STS) \\
\hline
\end{tabular}

2. Menentukan jumlah skor ideal atau skor tertinggi dan jumlah skor terendah dengan cara.

a. Untuk skor tertinggi $=$ skor alternative jawaban sangat setuju (SS) $\mathrm{x}$ jumlah siswa

b. Untuk skor terendah $=$ skor alternative jawaban sangat tidak setuju (STS) $\mathrm{x}$ jumlah siswa

c. Menentukan persentase setiap alternative jawaban dengan cara

$$
\frac{\text { Banyak jawaban siswa }}{\text { Jumlah siswa }} \times 100
$$


d. Selanjutnya memberikan skor total setiap pertanyaan dengan cara:

$$
\frac{\text { Jumlah skor jawaban siswa }}{\text { skor tertinggi }} \times 100
$$

e. Dari data analisis tersebut dikonversikan pada penilaian angket kepraktisan pembelajaran bahan ajar multimedia interaktif:

Tabel 4.

Kategori Penilaian Angket Kepraktisan Bahan Ajar Matematika [5]

\begin{tabular}{|cc|}
\hline Skor & Kategori Penilaian \\
\hline $81-100$ & Sangat Praktis \\
\hline $61-80$ & Praktis \\
\hline $41-60$ & Cukup Praktis \\
\hline $21-40$ & Kurang Praktis \\
\hline $0-20$ & Tidak Praktis \\
\hline
\end{tabular}

\section{Analisis Lembar Observasi}

Penilaian ini dilakukan dengan memberi tanda check $(\sqrt{ })$ pada lembar observasi.

Tabel 5.

Lembar Observasi

\begin{tabular}{|c|c|c|}
\hline \multirow{2}{*}{ No } & \multirow{2}{*}{ Pernyataan } & Skor \\
\hline & & 0 \\
\hline 1 & $\begin{array}{l}\text { Siswa mampu menggunakan tombol } \\
\text { yang ada pada bahan ajar } \\
\text { matematika menggunakan komputer }\end{array}$ & \\
\hline 2 & $\begin{array}{l}\text { Siswa mengerti petunjuk-petunjuk } \\
\text { yang ada pada bahan ajar } \\
\text { matematika } \\
\text { Komputer }\end{array}$ & \\
\hline 3 & $\begin{array}{l}\text { Siswa mengetahui lambang atau } \\
\text { symbol matematika }\end{array}$ & \\
\hline 4 & $\begin{array}{l}\text { Siswa mengerti bahasa yang } \\
\text { digunakan pada bahan ajar } \\
\text { matematika menggunakan computer }\end{array}$ & \\
\hline
\end{tabular}

Keterangan:

$0=$ Indikator tidak tampak

$1=$ Indikator tampak

Adapun langkah-langkah dalam menganalisis data observasi adalah sebagai berikut:

1. Menghitung skor yang diperoleh siswa untuk masing-masing indikator.
2. Menghitung berapa banyak siswa yang memperoleh skor observasi.

3. Memberikan skor total tiap pertemuan dengan cara :

$$
\mathrm{H}=\frac{\mathrm{JS}}{\mathrm{ST}} \mathrm{X} 100
$$

Keterangan [5]:

$\mathrm{H} \quad$ : Hasil Validasi

JS : Jumlah Skor

ST : Skor Maksimum

Tabel 6.

Kategori Skor Observasi

\begin{tabular}{|cc|}
\hline Skor & Kategori Penilaian \\
\hline $81-100$ & Sangat Praktis \\
\hline $61-80$ & Praktis \\
\hline $41-60$ & Cukup Praktis \\
\hline $21-40$ & Kurang Praktis \\
\hline $0-20$ & Tidak Praktis \\
\hline
\end{tabular}

\section{Hasil dan Pembahasan}

\section{A. Hasil Penelitian}

Penelitian ini dilakukan dalam beberapa tahap setelah peneliti menentukan materi yang akan dikembangkan tahap selanjutnya yaitu tahap desain produk di mana peneliti membuat desain produk bahan ajar yang dikembangkan, setelah desain produk selesai dibuat selanjutnya produk tersebut validasi oleh dosen dan guru untuk mengetahui apakah bahan ajar yang dikembangkan peneliti valid atau tidak untuk digunakan peserta didik. Hasil validasi tersebut adalah sebagai berikut:

Tabel 7.

Analisis Data Angket Validasi

\begin{tabular}{clc}
\multicolumn{3}{c}{ Analisis Data Angket Validasi } \\
\hline No & \multicolumn{1}{c}{ Nama Validator } & $\begin{array}{c}\text { Nilai } \\
\text { Validasi }\end{array}$ \\
\hline 1 & Sujinal Arifin, M.Pd. & 80,95 \\
\hline 2 & Imelda Saluza, S.Si., M.Sc. & 92,38 \\
\hline 3 & Andi Amza, S.Pd & 89,52 \\
\hline 4 & Hj. Irma Suryani, S.Pd., M.Pd.I & 88,57 \\
\hline 5 & Dra. Fatmawati & 91,43 \\
\hline 6 & Berina Jusanti, S.Pd & 89,52 \\
\hline & Rata-rata & 88,73
\end{tabular}


Setelah dilakukan penilaian dari lembar validasi diperoleh nilai rata-rata yaitu 88,73 yang berarti bahwa bahan ajar matematika yang dihasilkan sudah Valid.

Setelah produk divalidasi tahap selanjutnya yaitu memperbaiki produk tersebut kemudian produk yang telah di perbaiki diujicobakan kepada siswa. Uji coba ini dilakukan pada dua kelompok yaitu kelompok besar dan kelompok kecil. Uji coba yang dilakukan untuk mengetahui apakah produk atau bahan ajar yang dikembangkan peneliti praktis untuk digunakan siswa dalam belajar matematika. Hasil dari observasi dan angket respon siswa adalah sebagai berikut.

Tabel 8.

Kategori Hasil Angket Kepraktisan Bahan Ajar Matematika Kelompok Kecil

\begin{tabular}{|c|c|c|c|c|c|c|}
\hline No & Pernyataan & $\mathbf{S S}$ & $\mathbf{S}$ & TS & TST & Skor \\
\hline 1 & $\begin{array}{l}\text { Saya dapat menggunakan bahan ajar matematika ini untuk belajar } \\
\text { kesebangunan }\end{array}$ & 90 & 10 & 0 & 0 & 97,5 \\
\hline 2 & $\begin{array}{l}\text { Kalimat - kalimat dalam materi yang terdapat di bahan ajar } \\
\text { matematika ini dapat saya pahami }\end{array}$ & 60 & 40 & 0 & 0 & 90 \\
\hline 3 & Simbol - simbol yang digunakan dapat saya pahami dengan jelas & 40 & 60 & 0 & 0 & 85 \\
\hline 4 & $\begin{array}{l}\text { Saya dapat berpindah dari halaman lain tanpa harus urut membuka } \\
\text { halaman berikutnya }\end{array}$ & 60 & 20 & 20 & 0 & 85 \\
\hline 5 & Cara pemakaian bahan ajar matematika ini mudah bagi saya & 40 & 60 & 0 & 0 & 85 \\
\hline 6 & $\begin{array}{l}\text { Dengan adanya gambar saya dapat mengingat informasi yang saya } \\
\text { pelajari }\end{array}$ & 80 & 20 & 0 & 0 & 95 \\
\hline 7 & Saya dapat belajar mandiri menggunakan bahan ajar matematika ini & 50 & 50 & 0 & 0 & 87,5 \\
\hline 8 & $\begin{array}{l}\text { Menurut saya bahan ajar matematika ini dapat digunakan sebagai } \\
\text { alternative bagi saya }\end{array}$ & 60 & 40 & 0 & 0 & 90 \\
\hline & Skor rata-rata & & & & & 89,38 \\
\hline
\end{tabular}

Tabel 9.

Kategori Hasil Angket Kepraktisan Bahan Ajar Matematika Kelompok Besar

\begin{tabular}{|c|c|c|c|c|c|c|}
\hline No & Pernyataan & SS & $\mathbf{S}$ & TS & TST & Skor \\
\hline 1 & $\begin{array}{l}\text { Saya dapat menggunakan bahan ajar matematika ini untuk } \\
\text { belajar kesebangunan }\end{array}$ & 51,28 & 48,72 & 0 & 0 & 87,82 \\
\hline 2 & $\begin{array}{l}\text { Kalimat - kalimat dalam materi yang terdapat di bahan ajar } \\
\text { matematika ini dapat saya pahami }\end{array}$ & 38,46 & 61,54 & 0 & 0 & 90,38 \\
\hline 3 & $\begin{array}{l}\text { Simbol - simbol yang digunakan dapat saya pahami dengan } \\
\text { jelas }\end{array}$ & 25,64 & 69,23 & 5,13 & 0 & 80,13 \\
\hline 4 & $\begin{array}{l}\text { Saya dapat berpindah dari halaman lain tanpa harus urut } \\
\text { membuka halaman berikutnya }\end{array}$ & 25,64 & 64,1 & 10,26 & 0 & 78,85 \\
\hline 5 & Cara pemakaian bahan ajar matematika ini mudah bagi saya & 61,54 & 38,46 & 0 & 0 & 90,38 \\
\hline 6 & $\begin{array}{l}\text { Dengan adanya gambar saya dapat mengingat informasi } \\
\text { yang saya pelajari }\end{array}$ & 51,28 & 46,15 & 2,56 & 0 & 87,18 \\
\hline 7 & $\begin{array}{l}\text { Saya dapat belajar mandiri menggunakan bahan ajar } \\
\text { matematika ini }\end{array}$ & 33,33 & 61,54 & 5,13 & 0 & 82,05 \\
\hline 8 & $\begin{array}{l}\text { Menurut saya bahan ajar matematika ini dapat digunakan } \\
\text { sebagai alternative bagi saya }\end{array}$ & 43,59 & 53,85 & 2,56 & 0 & 85,26 \\
\hline
\end{tabular}

Berdasarkan hasil table 9 analisis pertemuan pertama didapatkan hasil angket kelompok besar di atas, pada persentase 89,38 yang berarti bahwa 
bahan ajar matematika yang digunakan dengan persentase 85,26 yang berarti praktis sedangkan pada pertemuan kedua didapatkan hasil angket respon siswa sangat praktis.

Tabel 10.

Analisis data observasi kelompok kecil

\begin{tabular}{|c|c|c|c|c|}
\hline \multirow{2}{*}{ No } & \multirow{2}{*}{ Pernyataan } & \multicolumn{3}{|c|}{ Skor pertemuan pertama } \\
\hline & & 0 & 1 & $\%$ Indikator \\
\hline 1 & $\begin{array}{l}\text { Siswa mampu menggunakan tombol yang ada pada bahan ajar } \\
\text { matematika menggunakan computer }\end{array}$ & 3 & 7 & 70 \\
\hline 2 & $\begin{array}{l}\text { Siswa mengerti petunjuk-petunjuk yang ada pada bahan ajar } \\
\text { matematika menggunakan computer }\end{array}$ & 2 & 8 & 80 \\
\hline 3 & Siswa mengetahui lambang atau symbol matematika & 4 & 6 & 60 \\
\hline 4 & $\begin{array}{l}\text { Siswa mengerti bahasa yang digunakan pada bahan ajar } \\
\text { matematika menggunakan computer }\end{array}$ & 0 & 10 & 100 \\
\hline \multicolumn{2}{|r|}{ Rata-rata } & & & 77,5 \\
\hline \multirow{2}{*}{ No } & \multirow{2}{*}{ Pernyataan } & \multicolumn{3}{|c|}{ Skor pertemuan pertama } \\
\hline & & 0 & 1 & $\%$ Indikator \\
\hline 1 & $\begin{array}{l}\text { Siswa mampu menggunakan tombol yang ada pada bahan ajar } \\
\text { matematika menggunakan computer }\end{array}$ & 0 & 10 & 100 \\
\hline 2 & $\begin{array}{l}\text { Siswa mengerti petunjuk-petunjuk yang ada pada bahan ajar } \\
\text { matematika menggunakan computer }\end{array}$ & 0 & 10 & 100 \\
\hline 3 & Siswa mengetahui lambang atau symbol matematika & 3 & 7 & 70 \\
\hline 4 & $\begin{array}{l}\text { Siswa mengerti bahasa yang digunakan pada bahan ajar } \\
\text { matematika menggunakan computer }\end{array}$ & 0 & 10 & 100 \\
\hline \multicolumn{2}{|r|}{ Rata-rata } & & & 92,5 \\
\hline
\end{tabular}

Berdasarkan hasil tabel 10 observasi digunakan praktis danpada pertemuan kelompok kecil yang terdiri dari 10 siswa kedua didapatkan hasil observasi dengan kelas IX A, pada pertemuan pertama persentase 92,5 yang berarti bahan ajar didapatkan hasil persentase 77,5 yang matematika yang digunakan sangat berarti bahwa bahan ajar matematika yang praktis.

Tabel 11.

Analisis data observasi kelompok besar

\begin{tabular}{|c|c|c|c|c|}
\hline \multirow{2}{*}{ No } & \multirow{2}{*}{ Pernyataan } & \multicolumn{3}{|c|}{ Skor pertemuan pertama } \\
\hline & & 0 & 1 & $\%$ Indikator \\
\hline 1 & $\begin{array}{l}\text { Siswa mampu menggunakan tombol yang ada pada bahan ajar } \\
\text { matematika menggunakan Komputer }\end{array}$ & 9 & 31 & 77,5 \\
\hline 2 & $\begin{array}{l}\text { Siswa mengerti petunjuk-petunjuk yang ada pada bahan ajar } \\
\text { matematika menggunakan computer }\end{array}$ & 4 & 36 & 90 \\
\hline 3 & Siswa mengetahui lambang atau symbol matematika & 25 & 15 & 37,5 \\
\hline 4 & $\begin{array}{l}\text { Siswa mengerti bahasa yang digunakan pada bahan ajar } \\
\text { matematika menggunakan computer }\end{array}$ & 0 & 40 & 100 \\
\hline \multicolumn{2}{|r|}{ Rata-rata } & & & 76,25 \\
\hline \multirow{2}{*}{ No } & \multirow{2}{*}{ Pernyataan } & \multicolumn{3}{|c|}{ Skor pertemuan pertama } \\
\hline & & 0 & 1 & $\%$ Indikator \\
\hline 1 & $\begin{array}{l}\text { Siswa mampu menggunakan tombol yang ada pada bahan ajar } \\
\text { matematika menggunakan computer }\end{array}$ & 0 & 39 & 100 \\
\hline 2 & Siswa mengerti petunjuk-petunjuk yang ada pada bahan ajar & 0 & 39 & 100 \\
\hline
\end{tabular}




\begin{tabular}{|llllll|}
\hline \multicolumn{1}{|l|}{ matematika menggunakan computer } & & & \\
\hline 3 & Siswa mengetahui lambang atau symbol matematika & 9 & 30 & 76,92 \\
\hline 4 & $\begin{array}{l}\text { Siswa mengerti bahasa yang digunakan pada bahan ajar } \\
\text { matematika menggunakan computer }\end{array}$ & 0 & 39 & 100 \\
\hline
\end{tabular}

Berdasarkan hasil tabel 11. observasi kelompok besar di atas, pada pertemuan pertama didapatkan hasil persentase 76,25 yang berarti bahwa bahan ajar matematika yang digunakan praktis dan pada pertemuan kedua didapatkan hasil observasi dengan persentase 94,23 yang berarti bahan ajar matematika yang digunakan sangat praktis.

\section{B. Pembahasan}

Singkatan yang sudah umum seperti seperti IPA, IPS, RPP, dan LKS tidak perlu diberi keterangan kepanjangannya. Akan tetapi, akronim yang tidak terlalu dikenal atau akronim bikinan penulis perlu diberi keterangan kepanjangannya. Sebagai contoh: "Pendekatan RME (Realistic Mathematics Education) dapat digunakan untuk memberikan pembelajaran yang diawali dengan suatu konteks". Jangan gunakan singkatan atau akronim pada judul artikel, kecuali tidak bisa dihindari.

Penelitian ini menghasilkan bahan ajar matematika menggunakan komputer. Setelah bahan ajar matematika selesai didesain dan divalidasi maka bahan ajar diujicobakan pada siswa.Peneliti menerapkan bahan ajar yang telah dikembangkan guna melihat apakah bahan ajar matematika yang dikembangkan peneliti praktis untuk digunakan siswa dalam belajar matematika pada materi kesebanngunan. Pada saat ujicoba bahan ajar matematika pada pertemuan pertama kelompok kecil yaitu pada 10 siswa kelas IX A terdapat kendala yaitu ruang laboratorium komputer tidak bisa digunakan peneliti untuk menerapkan bahan ajar matematika yang dikembangkan dikarenakan guru yang bertugas menyimpan kunci laboratorium komputer tidak bisa hadir, sehingga ujicoba pada pertemuan pertama dilaksanakan diruang laboratorium IPA dengan menggunakan laptop yang di telah siapkan peneliti yaitu 5 laptop. Untuk mengatasi hal tersebut pada pertemuan kedua untuk kelompok kecil peneliti telah menyiapkan laptop sebanyak 10 laptop sehingga walaupun tanpa menggunakan ruang laboratorium komputer penelitian pada kelompok kecil masih dapat berjalan karena siswa pada kelompok kecil hanya 10 siswa dari 40 siswa kelas IX A.

Pada tahap uji coba pemakaian bahan ajar yang diujicobakan pada kelas IX C berjumlah 40 siswa maka dari itu karena siswa pada kelompok besar terbilang banyak maka untuk mengatasi masalah seperti pada pertemuan pertama kelompok kecil, maka peneliti memastikan kembali bahwa pada saat ujicoba pemakaian ruang komputer dapat digunakan untuk ujicoba bahan ajar matematika yang telah dikembangkan peneliti.

Pada saat pelaksanaan ujicoba produk dan ujicoba pemakaian peneliti mengobservasi apakah siswa sudah bisa menggunakan bahan ajar yang dikembangkan peneliti. Pada saat 
mengobervasi proses pembelajaran menggunakan bahan ajar yang dikembangkan peneliti melihat manfaat bahan ajar bagi siswa yaitu kegiatan pembelajaran menggunakan bahan ajar matematika yang telah dikembangkan peneliti lebih menarik, hal ini dapat dilihat pada saat peneliti melakukan obsevasi pada kelompok kecil dan komentar siswa setelah pembelajaran menggunakan bahan ajar matematika yang telah dikembangkan. Siswa akan lebih mandiri dalam proses belajar mengajar sehingga mengurangi ketergantungan terhadap kehadiran guru. Dengan menggunakan bahan ajar matematika yang telah dikembangkan peneliti, siswa dapat belajar sendiri tanpa harus ada guru yang mengajarkan materi pelajaran matematika karena bahan ajar yang dikembangkan peneliti dikemas dalam file sehingga siswa dapat memindahkan file bahan ajar yang telah dikembangkan peneliti ke komputer atau laptop sendiri dan siswa dapat belajar mandiri dengan menggunakan bahan ajar matematika yang dikembangkan peneliti.Siswa merasa lebih mudah memahami dan mempelajari kompetensi yang harus dikuasai. Dengan adanya animasi-animasi yang dibuat peneliti dalam bahan ajar yang dikembangkan, maka siswa dapat lebih mudah memahami dan mempelajari materi kesebangunan

Hasil validasi yang telah dilakukan oleh validator menunjukkan nilai rata-rata 88,73 yang termasuk kategori sangat valid. Artinya bahan ajar matematika yang telah dikembangkan oleh peneliti sudah valid dan dapat digunakan dalam kegiatan pembelajaran matematika.
Hasil analisis observasi pada kelompok kecil diperoleh rata-rata 85 yang termasuk kategori sangat praktis dan pada kelompok besar diperoleh rata-rata 85,24 yang berarti bahan ajar matematika yang dikembangkan juga tergorong sangat praktis. Maka bahan ajar matematika yang dihasilkan memenuhi kiteria praktis.

Selain observasi, peneliti memberikan angket kepraktisan kepada siswa hal ini bertujuan agar siswa sendiri yang memberikan pendapat terhadap keterpakaian bahan ajar matematika bagi siswa dalam belajar matematika pada materi kesebangunan. Analisis data pada kelompok lecil didperoleh rata-rata skor angket yaitu 89,38 dengan kategori penilaian sangat praktis dan analisis data pada kelompok besar diperoleh rata-rata $85,26 y a n g$ juga tergolong kategori sangat praktis. Sehingga dari data tersebut didapatkan bahwa bahan ajar matematika praktis digunakan dalam pembelajaran matematika.

Berdasarkan beberapa uraian di atas bahan ajar matematika yang dikembangkan peneliti memenuhi kriteria valid dan praktis maka bahan ajar matematika yang dikembangkan peneliti memenuhi kriteria bahan ajar yang berkualitas.

\section{Penutup}

Berdasarkan hasil penelitian maka dapat disimpulkan sebagai berikut:

1. Bahan ajar matematika yang dikembangkan menggunakan komputer pada materi kesebangunan di kelas IX MTs Negeri 1 Palembang tergolong kategori valid. Hal ini terlihat dari 
penilaian validator, dimana rata-rata skor hasil penilaian validator adalah 88,73 yang berarti dari skor rata-rata yang diperoleh menunjukkan bahwa hasil validator tersebut tergolong kriteria valid.

2. Bahan ajar matematika yang dikembangkan menggunakan komputer pada materi kesebangunan di kelas IX MTs Negeri 1 Palembang tergolong kategori praktis. Hal ini terlihat dari angket respon siswa dan observasi yang dilakukan peneliti pada saat proses penlitian, dimana rata-rata skor hasil respon siswa adalah 87,32 yang berarti dari skor rata-rata yang diperoleh menunjukkan bahwa hasil respon siswa tersebut menunjukkan kriteria sangat praktis. Sedangkan rata-rata skor hasil observasi adalah 85,12 yang berarti dari skor rata-rata yang diperoleh menunjukan bahwa hasil observasi yang dilakukan menunjukan kriteria sangat praktis.

Adapun beberapa saran dari peneliti setelah melaksanakan penelitian ini yaitu kepada :

1. Bagi siswa dapat menggunakan bahan ajar matematika ini sebagai alternatif bagi siswa dalam pembelajaran materi kesebangun.

2. Bagi guru dapat memanfaatkan bahan ajar matematika ini sebagai alternatif agar siswa tidak merasa jenuh pembelajaran matematika dan dalam menyampaikan materi kesebangunan.

3. Bagi peneliti selanjutnya diharapkan untuk mengembangkan bahan ajar matematika pada materi kesebangunan dengan menambahkan simulasi dan animasi-animasi lainya sehingga membuat siswa lebih tertaik dalam pembelajaran matematika serta mengembangkannya pada materi matematika yang lain.

\section{Daftar Pustaka}

[1] Mastur Faizi, Ragam Metode Mengajarkan Eksakta Pada Murid, Jogjakarta DIVE press. 2013.

[2] Cecep Kustandi dan Bambang Sutjipto, Media Pembelajaran, Bogor: Ghalia Indonesia, 2013.

[3] Sugiyono, Metode Penelitian Pendidikan Alfabeta: Bandung, 2013.

[4] Nora Surmilasari, Pengembangan Multimedia Pada Pokok Bahasan Menentukan Jarak pada Bangun Ruang di kelas X SMA, UNSRI, Tesis. 2013.

[5] Suharsimi Arikunto, Dasar-dasar Evaluasi Pendidikan, Jakarta: Bumi Aksara 2009.

[6] Riduwan, Metode dan Teknik menyusun Tesis, Bandung: Alfabeta, 2013. 

e-mosharafa.org

This page is intentionally left blank 